\title{
Gambaran Histopatologi dan Populasi Bakteri Asam Laktat pada Duodenum Ayam Pedaging yang Diberi Sinbiotik dan Diinfeksi Escherichia coli
}

\author{
(HISTOPATHOLOGY AND LACTICACID BACTERIA \\ POPULATION IN DUODENUM WITH SINBIOTIC \\ AND ESCHERICHIA COLI INFECTED BROILER)
}

Muhammad Daud, Muhammad Aman Yaman, Zulfan

Program Studi Peternakan,

Fakultas Pertanian, Universitas Syiah Kuala, Jl. Tgk. Hasan Krueng Kalee, Kopelma Darussalam, Syiah Kuala, Kota Banda Aceh, Aceh, Indonesia 23111

Telp. 08116871104; Email: daewood_vt@yahoo.co.id

\begin{abstract}
ABSTRAK
Penelitian bertujuan untuk mengevaluasi penggunaan sinbiotik sebagai feed additive dalam ransum terhadap gambaran histopatologi dan populasi bakteri asam laktat (BAL) pada duodenum ayam pedaging yang diinfeksi bakteri Escherichia coli. Penelitian menggunakan 96 ekor ayam pedaging strain Jumbo seri A Cibadak yang dipelihara sampai umur enam minggu. Penelitian dilakukan dengan metode eksperimen, menggunakan Rancangan Acak Lengkap (RAL) dengan delapan perlakuan ransum dan empat ulangan. Perlakuan ransum terdiri atas: R1 (ransum basal/ kontrol), R2 (ransum basal + prebiotik 0,4\%), R3 (ransum basal + probiotik $10^{8} \mathrm{CFU}$ ), R4 (ransum basal + prebiotik $0,4 \%+$ probiotik $10^{8} \mathrm{CFU} /$ sinbiotik), R5 (ransum basal + infeksi E. coli $10^{4} \mathrm{CFU}$ ), R6 (ransum basal + prebiotik 0,4\% + infeksi $E$. coli $10^{4} \mathrm{CFU}$ ), R7 (ransum basal + probiotik $10^{8}$ $\mathrm{CFU}+$ infeksi E. coli $10^{4} \mathrm{CFU}$ ), dan R8 (ransum basal + prebiotik $0,4 \%+$ probiotik $10^{8} \mathrm{CFU}+$ infeksi E.coli $10^{4} \mathrm{CFU}$ ). Variabel yang diamati adalah perubahan histopatologi duodenum berdasarkan skor lesio mikroskopik dan populasi BAL pada duodenum ayam pedaging umur 2, 4, dan 6 minggu. Analisis data dilakukan dengan sidik ragam satu arah, dilanjutkan dengan uji Duncan. Hasil penelitian menunjukkan penggunaan probiotik, prebiotik dan sinbiotik secara signifikan $(\mathrm{P}<0,05)$ menurunkan skor lesio mikroskopik duodenum dan terjadi peningkatan populasi BAL pada duodenum ayam pedaging umur 2, 4 dan 6 minggu. Disimpulkan bahwa penggunaan sinbiotik sebagai feed additive dalam ransum dapat memberi pengaruh positif terhadap histopatologi duodenum dan populasi BAL pada duodenum ayam pedaging umur 2, 4 dan 6 minggu baik yang diinfeksi maupun yang tidak diinfeksi E.coli.
\end{abstract}

Kata-kata kunci: ayam pedaging; sinbiotik; histopatologi; duodenum; BAL

\begin{abstract}
The research aims to study the use of synbiotics as feed additives in rations on describe lesions histopathology and population of lactic acid bacteria in duodenum infected with Escherichia coli. The study used 96 broiler Jumbo series A Cibadak strains which were maintained until the age of six weeks. The study was conducted by experimental method, using a completely randomized design (CRD) with eight treatments of rations and four replications. The broilers were devided into eight treatment diets: R1 (basal diet/control), R2 (basal diet + prebiotic 0.4\%); R3 (basal diet + probiotic $10^{8} \mathrm{CFU}$ ); R4 (basal diet + prebiotic $0.4 \%$ + probiotic $10^{8} \mathrm{CFU}$ ); R5 (basal diet + infected with E. coli $10^{4} \mathrm{CFU}$ ); R6 (basal diet + prebiotic $0.4 \%$ + infected with E. coli $10^{4} \mathrm{CFU}$ ); R7 (basal diet + probiotic $10^{8} \mathrm{CFU}+$ infected with E. coli $10^{4} \mathrm{CFU}$ ); and R8 (basal diet + prebiotic $0.4 \%$ + probiotic $10^{8} \mathrm{CFU}$ + infected with E. coli $10^{4} \mathrm{CFU}$ ). The observed variables were histopathology based on lesio microscopic
\end{abstract}


and lactic acid bacteria population in duodenum age 2, 4 and 6 weeks. Data was analyzed by using one-way analysis of variance then continued with Duncan test. The results showed that the use of probiotics, prebiotics and synbiotics significantly $(\mathrm{P}<0.05)$ decreased histopathological lesio score and increased the population of lactic acid bacteria in duodenum age 2,4 and 6 weeks. In conclusion the use of synbiotics as feed additives in the ration a positive on describe lesions histopathological and increase in the population of lactic acid bacteria in duodenum age 2, 4 and 6 weeks infected and not infected with $E$. coli.

Keywords: broiler; sinbiotic; histopathology; duodenum; BAL

\section{PENDAHULUAN}

Penggunaan imbuhan pakan atau feed additive dalam usaha peternakan unggas modern (ayam pedaging) sudah umum digunakan dengan tujuan untuk memacu pertumbuhan atau meningkatkan produktivitas dan efisiensi pakan. Salah satu faktor yang paling penting dalam meningkatkan produktivitas ternak adalah kesehatan saluran pencernaan. Tanpa didukung saluran pencernaan yang sehat, ternak tidak dapat menunjukkan performans yang optimal. Kesehatan saluran pencernaan dan nutrisi saling berkaitan satu sama lain. Pemanfaatan nutrisi pakan hanya dapat dicapai secara optimal jika saluran pencernaan dalam keadaan sehat. Sistem pencernaan berhubungan langsung dengan lingkungan luar, sehingga merupakan tempat masuknya mikroorganisme patogen secara potensial dan menyebabkan saluran cerna mudah terinfeksi oleh agen infeksi seperti bakteri, dan cacing sehingga dapat menyebabkan gangguan absorbsi nutrisi seperti elektrolit-elektrolit, vitamin-vitamin, dan mineral yang berimplikasi pada perlambatan pertumbuhan serta dapat menimbulkan kerusakan vili usus (Balqis et al., 2011). Pertumbuhan vili pada saluran pencernaan dapat memengaruhi performans pertumbuhan ayam (Yazdi et al., 2014; Khan et al., 2017).

Produktivitas ternak dapat ditingkatkan salah satunya yaitu dengan pemberian imbuhan pakan. Imbuhan pakan yang sangat umum digunakan adalah antibiotik atau lebih dikenal dengan Antibiotic Growth Promoter (AGP) yang berfungsi untuk membantu melawan bakteri patogen dan akibatnya dapat meningkatkan produksi ternak. Antimikrob khususnya antibiotik, pada hewan produksi digunakan sebagai terapi, pencegahan penyakit, dan juga digunakan sebagai pemacu pertumbuhan (Ventola, 2016). Dosis AGP pada umumnya sekitar 2,5-50,0 ppm (Hashemi dan Davoodi, 2010). Meskipun dosis yang digunakan dalam konsentrasi kecil, penggunaan antibiotik telah mendapat perhatian khusus dari pemerintah dan konsumen. Akibat pemberian antibiotik tertentu, ternak resisten terhadap Enrofloxacin yang berfungsi untuk membasmi bakteri Escherichia coli. Secara keilmuan, penggunaan AGP dinilai ber-hasil dan mampu memperbaiki nilai feed coversion ratio (FCR). Namun, WHO telah melarang penggunaan AGP pada hewan ternak karena dapat berakibat buruk bagi kesehatan manusia. Begitu juga FAO, menyatakan penggunaan antibiotik menjadi ancaman bagi manusia, karena mikrob yang harusnya dapat dibasmi dengan antibiotik ternyata tidak. Uni Eropa telah melarang penggunaan antibiotik sebagai pemacu pertumbuhan sejak tahun 2006 (Marshall dan Levy, 2011). Namun di Indonesia, pelarangan AGP baru mulai berlaku sejak 1 Januari 2018, dan hal tersebut sebenarnya telah diatur dalam Undang-Undang Nomor 18 tahun 2009 juncto Undang-Undang Nomor 41 tahun 2014 tentang Peternakan dan Kesehatan Hewan. Pasal 22 ayat 4c dinyatakan, setiap orang dilarang menggunakan pakan yang dicampur hormon tertentu dan atau antibiotik sebagai imbuhan pakan.

Upaya meningkatkan produktivitas dan mempertahankan kesehatan saluran pencernaan harus selalu dilakukan. Salah satunya dengan pemberian pakan yang seimbang dan pemberian sinbiotik sebagai imbuhan pakan atau feed additive. Sinbiotik merupakan suatu produk yang mengandung dua jenis bahan yaitu probiotik dan prebiotik. Probiotik adalah sekelompok mikrob hidup yang menguntungkan dan digunakan untuk memengaruhi induk semang melalui perbaikan mikroorganisme di saluran pencernaan (Fuller, 1997). Mikroorganisme probiotik yang paling banyak digunakan 
adalah strain Lactobacillus dan Bifidobacteria (Solanki et al., 2013), sedangkan prebiotik adalah nondigestible food ingredient yang memiliki pengaruh baik terhadap host (inang) dengan memicu aktivitas, pertumbuhan selektif, atau keduanya terhadap satu jenis atau lebih mikrob penghuni kolon (Salminen dan Yuan 2009).

Sinbiotik yang digunakan pada penelitian ini adalah sinbiotik alami yang terdiri dari bakteri asam laktat $L$. casei Rhamnosus sebagai probiotik dan oligosakarida ekstraksi tepung buah rumbia sebagai prebiotik. Tujuan penelitian adalah untuk mengevaluasi penggunaan sinbiotik sebagai feed additive dalam ransum terhadap gambaran histopatologi dan populasi BAL pada duo-denum ayam pedaging yang diinfeksi bakteri $E$. coli.

\section{METODE PENELITIAN}

Materi penelitian yang digunakan adalah ayam pedaging umur sehari (Day Old Chick) DOC strain Jumbo seri A Cibadak sebanyak 96 ekor, yang dipelihara sampai umur enam minggu. Pada hari pertama dilakukan penimbangan DOC dan selanjutnya DOC ditempatkan pada kandang perlakuan dan ulangan sesuai dengan unit kandang pengacakan. Pada hari keempat, ayam pedaging divaksinasi ND guna mencegah timbulnya penyakit tetelo (ND) melalui tetes mata. Infeksi bakteri E.coli dilakukan pada umur tujuh hari dengan cara injeksi kedalam mulut ayam pedaging sebanyak $10^{4} \mathrm{CFU} /$ ekor.

\section{Metode Penelitian}

Penelitian dilakukan dengan metode eksperimen, menggunakan Rancangan Acak Lengkap (RAL), dengan delapan perlakuan ransum dan empat kali ulangan. Perlakuan ransum terdiri atas: R1 (ransum basal/kontrol), R2 (ransum basal + prebiotik 0,4\%), R3 (ransum basal + probiotik $\left.10^{8} \mathrm{CFU}\right), \mathrm{R} 4$ (ransum basal + prebiotik $0,4 \%+$ probiotik $10^{8} \mathrm{CFU} /$ sinbiotik), R5 (ransum basal + infeksi $E$. coli $10^{4}$ CFU), R6 (ransum basal + prebiotik $0,4 \%+$ infeksi $E$. coli $10^{4} \mathrm{CFU}$ ), $\mathrm{R} 7$ (ransum basal + probiotik $10^{8} \mathrm{CFU}$ + infeksi E. coli $10^{4} \mathrm{CFU}$ ), dan R8 (ransum basal + prebiotik 0,4\% + probiotik $10^{8} \mathrm{CFU}+$ infeksi E.coli $\left.10^{4} \mathrm{CFU}\right)$.

\section{Ransum Penelitian}

Ransum yang digunakan selama penelitian adalah ransum basal tanpa antibiotik berbentuk crumble, yang diformulasikan sesuai kebutuhan ayam pedaging yaitu: ransum periode starter (umur 0-3 minggu) kandungan protein 21-23\% dan energi metabolisme $2800-3000 \mathrm{kkal} / \mathrm{kg}$, dan ransum periode finisher (umur 3-6 minggu) kandungan protein $19-21 \%$ dan energi metabolisme 3000-3200 kkal/kg. Semua ransum perlakuan menggunakan bahan pakan yang sama, hanya berbeda pada penggunaan probiotik, prebiotik dan sinbiotik. Bahan ransum yang digunakan terdiri atas: jagung kuning, bungkil kedelai, tepung ikan, dedak gandum, bungkil kelapa, CPO, DL-Methionine, LLysine, probiotik (L.casei Rhamnosus), dan prebiotik (oligosakarida ekstrak tepung buah rumbia).

\section{Variabel Penelitian}

Variabel yang diamati adalah gambaran histopatologi dan populasi bakteri asam laktat (BAL) pada duodenum ayam pedaging umur 2 , 4, dan 6 minggu. Pemeriksaan histopatologi dilakukan di Laboratorium Patologi, Fakultas Kedokteran Hewan, dan pengamatan terhadap populasi bakteri asam laktat (BAL) dilakukan di Laboratorium Mikrobiologi Seafast Center, Institut Pertanian Bogor.

Gambaran histopatologi diamati berdasarkan skor lesio mikroskopik duodenum ayam pedaging umur 2, 4, dan 6 minggu. Setiap pengamatan menggunakan satu ekor ayam/ ulangan yang diambil (dipotong) secara acak. Masing-masing sampel usus bagian duodenum diambil sepanjang $2 \mathrm{~cm}$ kemudian diblok dalam parafin. Sampel difiksasi dalam larutan buffer normal formalin (BNF) 10\%, didehidrasi dengan alkohol konsentrasi bertingkat, clearing dilakukan dengan $x y l o l$ dan embedding dengan menggunakan parafin. Preparat dipotong setebal $5 \mu \mathrm{m}$ dan dilekatkan pada gelas objek dan diwarnai dengan pewarnaan Hematoxilin dan Eosin (HE).

Selanjutnya dilakukan pengamatan lesio histopatologi dengan menggunakan mikroskop (Olympus) cahaya pada pembesaran lensa objektif 10, 20 atau 40 kali terhadap kerusakan organ pencernaan (duodenum) yang dinilai pada 10 bidang pandang berdasarkan derajat perubahannya, dengan skala tingkat kerusakan sebagai berikut: 0 = normal (vili utuh, mukosa normal, dan epitel tersusun rapi dengan sel goblet); 1 = rusak ringan (edema, dan pemendekan vili); 2 = rusak sedang (vili terkoyak ringan/tumpul, dan sel goblet berproliferasi); dan $3=$ rusak parah (nekrosis sel goblet, dan infiltrasi seluler pada vili). 
Pengamatan terhadap mikrobiota usus bakteri asam laktat (BAL) dilakukan pada usus bagian duodenum ayam pedaging umur 2,4 , dan 6 minggu. Setiap pengamatan menggunakan satu ekor ayam/ulangan yang diambil (dipotong) secara acak. Sampel berupa isi duodenum diambil sebanyak $0,5 \mathrm{~g}$, selanjutnya dilakukan pengenceran secara serial dan dilakukan kultur pada cawan petri dengan menggunakan media De Man, Rogosa dan Sharpe agar (MRS agar) kemudian diinkubasi pada suhu $37^{\circ} \mathrm{C}$ selama 24 jam. Pengamatan yang dilakukan yaitu menghitung jumlah koloni bakteri yang terbentuk (CFU).

\section{Analisis Data}

Data yang diperoleh dianalisis dengan sidik ragam dan data yang berbeda nyata dilanjutkan dengan uji Duncan's Multiple Range Test (Steel dan Torrie 1995). Data hasil pemeriksaan histopatologi yang terdapat dari pengamatan preparat jaringan masing-masing organ ditampilkan dalam bentuk gambar dan nilai skoring. Selanjutnya data dianalisis dengan membandingkan gambaran perubahan histopatologi pada organ duodenum ayam pedaging baik yang diinfeksi maupun yang tidak diinfeksi bakteri E. coli.

\section{HASIL DAN PEMBAHASAN}

\section{Gambaran Histopatologi Duodenum}

Hasil penelitian menunjukkan bahwa pemberian prebiotik, probiotik dan sinbiotik dalam ransum ayam pedaging tidak menunjukkan efek negatif terhadap kondisi usus (duodenum) yang tercermin dari skor lesio relatif lebih rendah dibandingkan skor lesio yang diperoleh pada perlakuan kontrol yang diinfeksi E.coli. Semakin kecil skor lesio yang dimiliki mengindikasikan kondisi organ pencernaan ayam pedaging semakin baik dan sebaliknya semakin besar skor lesio yang diperoleh menunjukkan tingkat kerusakan semakin parah (Tabel 1).

Infeksi E.coli pada ayam pedaging menimbulkan perubahan mikroskopik pada usus bagian duodenum yang ditandai dengan vili duodenum mengalami kerusakan (Gambar $2,4,6)$ dan skor lesio yang diperoleh pada minggu ke 2, 4 dan 6 secara signifikan $(\mathrm{P}<0,05)$ lebih tinggi dibandingkan dengan perlakuan lainnya. Vili yang mengalami kerusakan, akan mengganggu proses penyerapan makanan di dalam usus halus. Selain itu, luas permukaannya akan digunakan oleh bakteri patogen (E. coli) untuk menempel dan berkoloni, sehingga dapat memberikan pengaruh negatif terhadap perkembangan usus halus ayam pedaging. Bakteri patogen muncul dalam bentuk kolonisasi di dalam usus pada vili dan lapisan usus. Bakteri patogen akan berkembang biak dan menyebabkan kerusakan pada vili usus sehingga mengurangi penyerapan zat gizi. Hartono et al. (2016) menyatakan penurunan luas permukaan vili akan membatasi penyerapan sari-sari makanan. Dengan

Tabel 1. Rataan skor lesio mikroskopik duodenum ayam pedaging

\begin{tabular}{lccc}
\hline Perlakuan & \multicolumn{3}{c}{ Umur (minggu) } \\
\cline { 2 - 4 } & 2 & 4 & 6 \\
\hline R1 (Kontrol) & $0,60 \pm 0,54^{\mathrm{b}}$ & $0,27 \pm 0,26^{\mathrm{c}}$ & $0,42 \pm 0.124^{\mathrm{d}}$ \\
R2 (Prebiotik) & $0,65 \pm 0,42^{\mathrm{b}}$ & $0,80 \pm 0,54^{\mathrm{bc}}$ & $0,70 \pm 0,40^{\mathrm{cd}}$ \\
R3 (Probiotik) & $0,85 \pm 0,34^{\mathrm{b}}$ & $0,77 \pm 0,35^{\mathrm{bc}}$ & $1,05 \pm 0,43^{\mathrm{bc}}$ \\
R4 (Sinbiotik) & $0,65 \pm 0,25^{\mathrm{ab}}$ & $0,52 \pm 0,26^{\mathrm{bc}}$ & $0,57 \pm 0,29^{\mathrm{cd}}$ \\
R5 (Kontrol+infeksi E.coli) & $2,02 \pm 0,49^{\mathrm{a}}$ & $1,77 \pm 0,98^{\mathrm{a}}$ & $1,65 \pm 0,28^{\mathrm{a}}$ \\
R6 (Prebiotik+infeksi E.coli) & $0,87 \pm 0,20^{\mathrm{b}}$ & $1,17 \pm 0,17^{\mathrm{ab}}$ & $0,80 \pm 0,24^{\mathrm{bcd}}$ \\
R7 (Probiotik+infeksi E.coli) & $1,07 \pm 0,42^{\mathrm{b}}$ & $1,00 \pm 0,33^{\mathrm{bc}}$ & $1,20 \pm 0,29^{\mathrm{b}}$ \\
R8 (Sinbiotik+infeksi E.coli) & $0,62 \pm 0,28^{\mathrm{b}}$ & $0,77 \pm 0,41^{\mathrm{bc}}$ & $0,52 \pm 0,25^{\mathrm{d}}$ \\
\hline
\end{tabular}

Keterangan: Nilai rataan dengan superskrip yang berbeda pada kolom yang sama menunjukkan pengaruh yang berbeda nyata $(\mathrm{P}<0,05)$. Angka pada Tabel diperoleh dari hasil pengamatan duodenum dengan mikroskop pada 10 bidang pandang kemudian dibuat skala dengan tingkat kerusakan sebagai berikut:

0 = normal (vili utuh, mukosa normal, dan epitel tersusun rapi dengan sel goblet);

1 = rusak ringan (odema, dan pemendekan vili);

2 = rusak sedang (vili terkoyak ringan/tumpul, dan sel goblet berproliferasi); dan

$3=$ rusak parah (nekrosis sel goblet, dan infiltrasi seluler pada vili). 
demikian ayam yang diinfeksi E.coli dapat terganggu absorbsi nutrisinya yang berimplikasi pada hambatan pertambahan bobot badan. Kehilangan bobot badan erat kaitannya dengan keterbatasan kemampuan absorbsi nutrien oleh vili saluran cerna yang mengalami kerusakan.

Hasil penelitian menunjukkan bahwa pemberian prebiotik, probiotik dan sinbiotik dalam ransum ayam pedaging cenderung memiliki tingkat kerusakan usus bagian duodenum lebih rendah dibanding dengan perlakuan kontrol yang diinfeksi $E$. coli. Hal ini mengindikasikan bahwa penggunaan prebiotik, probiotik dan sinbiotik dalam ransum ayam pedaging tidak memberikan efek negatif terhadap ekosistem usus halus, bahkan sebaliknya pemberian prebiotik, probiotik dan sinbiotik dapat mempertahankan kondisi usus halus tetap baik meskipun ayam telah diinfeksi E. coli. Hal ini diduga disebabkan oleh adanya prebiotik, probiotik dan sinbiotik yang berperan menekan keberadaan bakteri $E$. coli. Hasil pengamatan histopatologi usus halus pada bagian duodenum (Gambar 7 dan 8) yang diberikan sinbiotik tidak ditemukan adanya kerusakan vili baik yang diinfeksi maupun yang tidak diinfeksi $E$. coli (gambaran vili masih utuh) yang ditandai dengan: 1 ) bentuk vili usus yang utuh tanpa ada koyakan pada permukaannya, 2) sel goblet dalam jumlah besar di setiap vilivili usus, dan 3) tidak ditemui adanya sarang radang yang merupakan salah satu indikasi usus terserang bakteri patogen.

Di dalam usus prebiotik bertindak sebagai umpan penarik patogen, sehingga permukaan

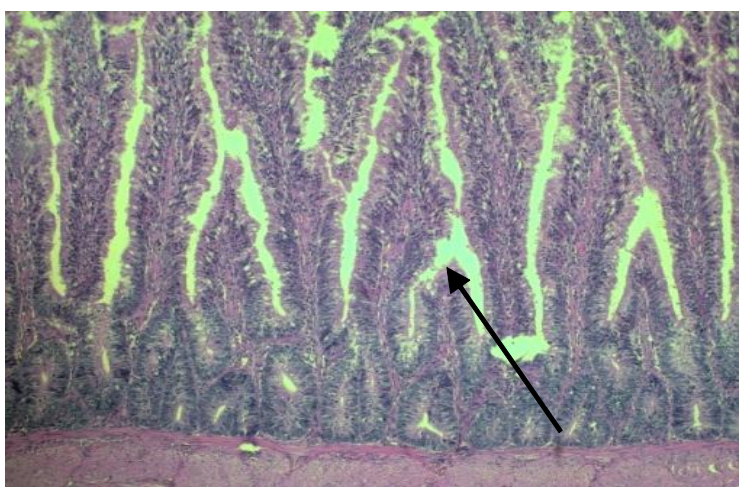

Gambar 1. Fotomikrograf duodenum ayam pedaging pada perlakuan R1 (kontrol) terjadi pemendekan vili/vili atrofi (HE, 10x) vili menjadi sehat dan dapat menyerap nutrisi secara efisien dan membuat lingkungan usus lebih sehat dan performans ayam lebih baik. Laudadio et al. (2012) menyatakan semakin tinggi vili maka luas daerah absorpsi nutrien akan semakin besar serta memengaruhi peningkatan laju pertumbuhan dan metabolisme. Selain itu, kapasitas pencernaan dan absorpsi nutrien juga dapat diketahui dari rasio vili. Semakin tinggi rasio vili, maka semakin tinggi pula tingkat pencernaan dan absorpsi nutriennya (Saragih et al., 2017). Sementara itu Setiawan et al. (2018) melaporkan bahwa pemberian serbuk daun jambu biji, dengan dosis $10 \mathrm{~g} / \mathrm{kg}$ pakan dapat meningkatkan pertumbuhan vili duodenum ayam jawa super umur 16 hari.

\section{Populasi Bakteri Asam Laktat (BAL)}

Distribusi dan dominasi mikrob dalam saluran pencernaan berbeda pada setiap bagian saluran pencernaan, misalnya dominasi mikrob dalam sekum berbeda dengan dominasi mikrob dalam ileum (Abdel-Raheem et al., 2012). Demikian juga halnya populasi bakteri asam laktat (BAL) yang diperoleh pada penelitian ini menunjukkan hasil yang berbeda pada saluran pencernaan bagian doudenum. Penggunaan prebiotik, probiotik dan sinbiotik dalam ransum ayam pedaging umur 2, 4, dan 6 minggu memberi pengaruh yang nyata $(\mathrm{P}<0,05)$ terhadap populasi BAL pada duodenum. Demikian juga halnya populasi BAL pada duodenum ayam pedaging yang diinfeksi E. coli namun diberi prebiotik, probiotik dan sinbiotik dalam ransum lebih tinggi $(\mathrm{P}<0,05)$ dibandingkan perlakuan kontrol (Tabel 2).

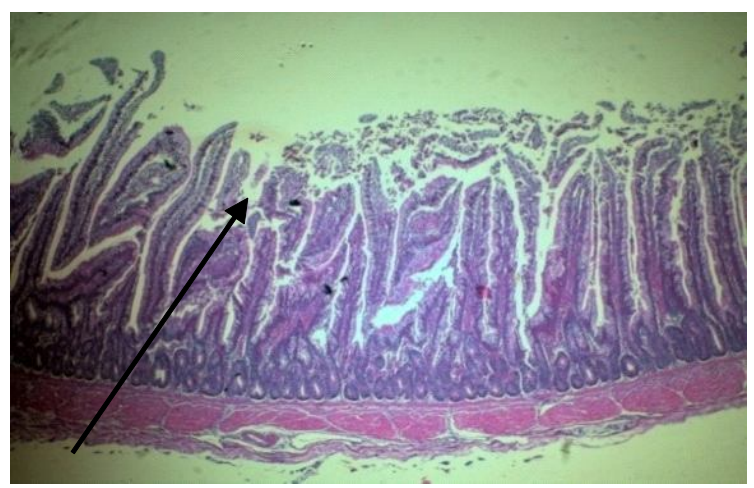

Gambar 2. Fotomikrograf duodenum ayam pedaging pada perlakuan R5 (kontrol + E.coli) vili terjadi kerusakan, vili terkoyak, vili atrofi, dan nekrosis sel goblet (HE, 10x) 


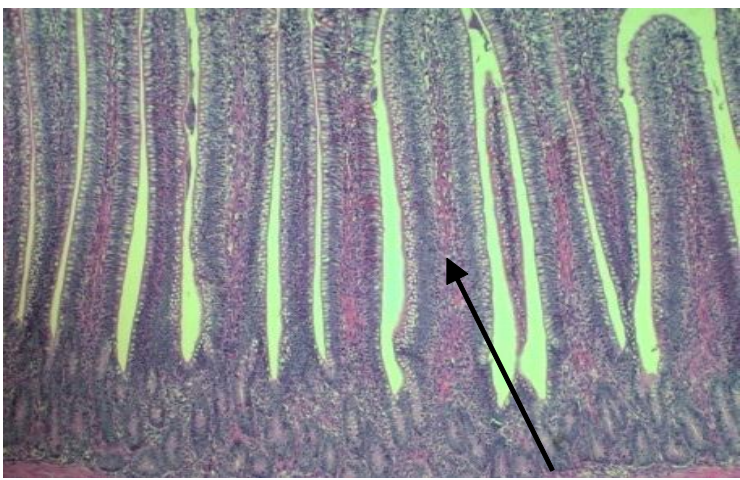

Gambar 3. Fotomikrograf duodenum ayam pedaging pada perlakuan R2 (prebiotik) vili dalam keadaan normal/utuh tanpa kerusakan (HE, 10x)

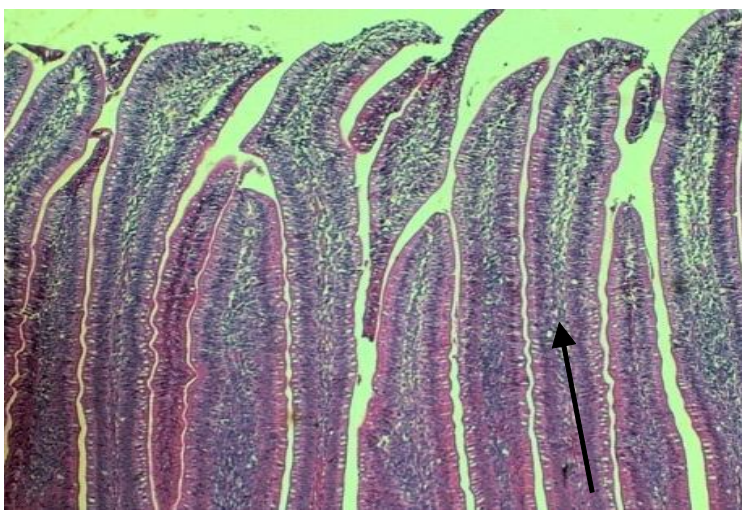

Gambar 5. Fotomikrograf duodenum ayam pedaging pada perlakuan R3 (probiotik) vili dalam keadaan normal/utuh tanpa kerusakan (HE, 10x)

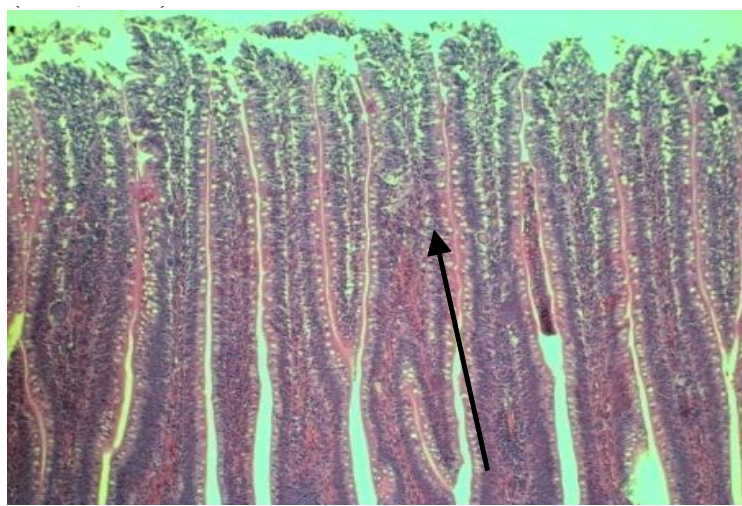

Gambar 7. Fotomikrograf duodenum ayam pedaging pada perlakuan R4 (sinbiotik) vili normal/utuh dan terjadi hyperplasia sel goblet $(\mathrm{HE}$, 10x)

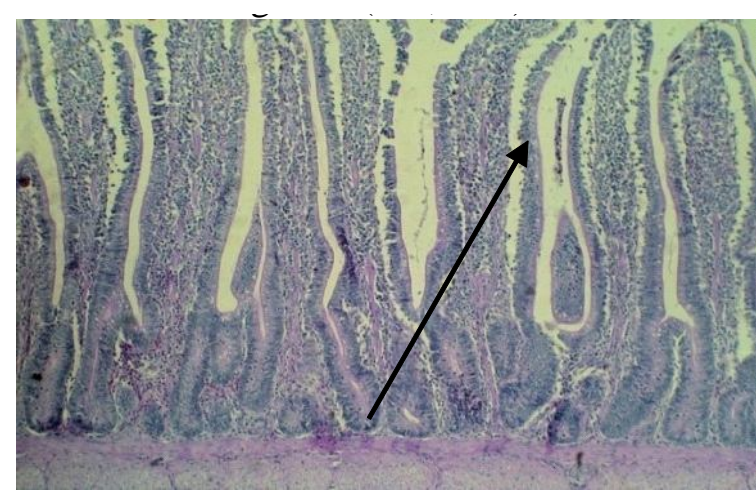

Gambar 4. Fotomikrograf duodenum ayam pedaging pada perlakuan R6 (prebiotik + E.coli) terjadi odema (HE, 10x)

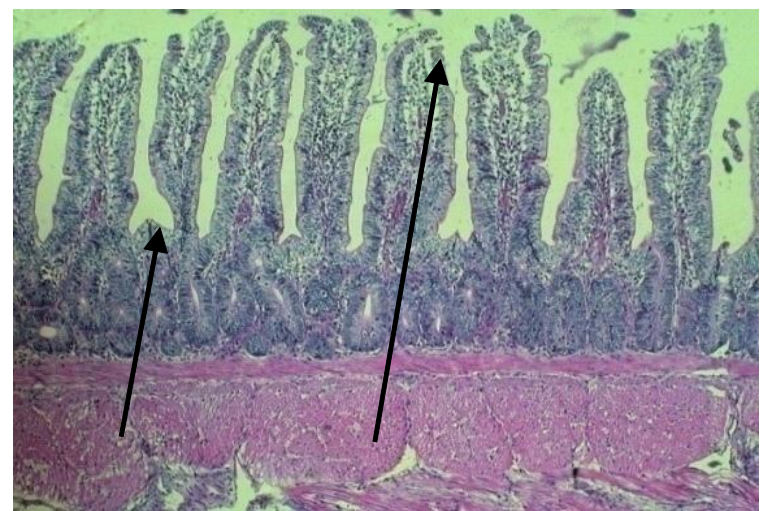

Gambar 6. Fotomikrograf duodenum ayam pedaging pada perlakuan R7 (probiotik $+E$.coli) terjadi odema dan pemendekan vili/vili atrofi (HE, 10x)

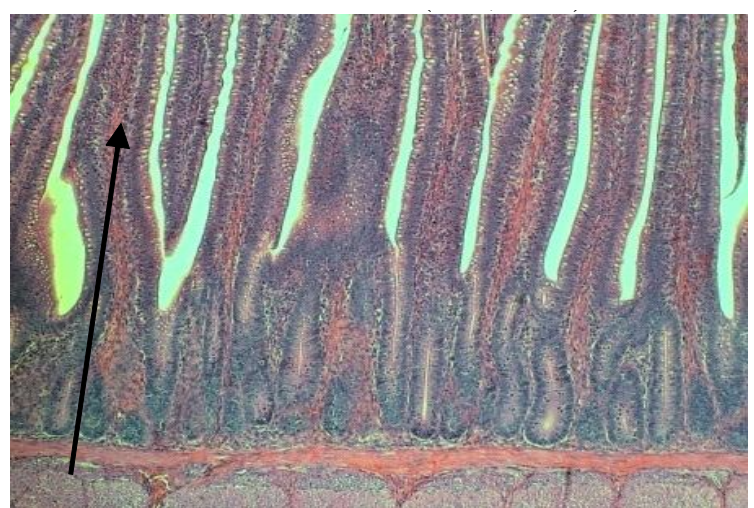

Gambar 8. Fotomikrograf duodenum ayam pedaging pada perlakuan R8 (sinbiotik + E.coli) vili normal/utuh tanpa kerusakan (HE, 10x) 
Tabel 2. Populasi bakteri asam laktat (BAL) pada duodenum ayam pedaging (Log cfu/mL)

\begin{tabular}{lccc}
\hline Perlakuan & \multicolumn{3}{c}{ Umur (minggu) } \\
\cline { 2 - 4 } & 2 & 4 & 6 \\
\hline R1 (Kontrol) & $4,32 \pm 2,53^{\mathrm{b}}$ & $6,69 \pm 0,09^{\mathrm{d}}$ & $5,80 \pm 0,40^{\mathrm{f}}$ \\
R2 (Prebiotik) & $7,24 \pm 0,32^{\mathrm{a}}$ & $7,05 \pm 0,01^{\mathrm{cd}}$ & $6,54 \pm 0,17^{\mathrm{d}}$ \\
R3 (Probiotik) & $8,02 \pm 0,02^{\mathrm{a}}$ & $7,67 \pm 1,03^{\mathrm{abc}}$ & $7,94 \pm 0,01^{\mathrm{ab}}$ \\
R4 (Sinbiotik) & $7,97 \pm 0,95^{\mathrm{a}}$ & $7,89 \pm 0,00^{\mathrm{ab}}$ & $7,97 \pm 0,00^{\mathrm{a}}$ \\
R5 (Kontrol+infeksi E.coli) & $6,19 \pm 0,18^{\mathrm{a}}$ & $6,78 \pm 0,61^{\mathrm{d}}$ & $6,97 \pm 0,03^{\mathrm{c}}$ \\
R6 (Prebiotik+infeksi E.coli) & $7,45 \pm 0,59^{\mathrm{a}}$ & $8,29 \pm 0,12^{\mathrm{a}}$ & $6,27 \pm 0,05^{\mathrm{e}}$ \\
R7 (Probiotik+infeksi E.coli) & $6,30 \pm 1,48^{\mathrm{a}}$ & $6,54 \pm 0,27^{\mathrm{d}}$ & $6,39 \pm 0,05^{\mathrm{de}}$ \\
R8 (Sinbiotik+infeksi E.coli) & $7,66 \pm 0,72^{\mathrm{a}}$ & $7,20 \pm 0,37^{\mathrm{bcd}}$ & $7,72 \pm 0,02^{\mathrm{b}}$ \\
\hline
\end{tabular}

Keterangan : Nilai rataan dengan superskrip yang berbeda pada kolom yang sama menunjukkan pengaruh yang berbeda nyata $(\mathrm{P}<0,05)$

Hasil penelitian menunjukkan bahwa penggunaan prebiotik, dan sinbiotik dalam ransum ayam pedaging mampu meningkatkan populasi BAL. Kebanyakan prebiotik yang telah diteliti merupakan jenis oligosakarida yang tidak dapat dicerna usus halus yang pada gilirannya akan masuk ke usus besar. Selanjutnya akan difermentasi oleh bakteribakteri yang menguntungkan di dalam usus besar (kolon), sehingga meningkatkan pertumbuhan BAL seperti Lactobacillus dan Bifidobacteria di dalam saluran pencernaan (Ashayeizadeh et al., 2011).

Menurut Ballongue (2004), keseimbangan ekosistem saluran gastrointestinal dapat terjaga melalui beberapa faktor, berupa mekanisme secara fisik, kimia dan pengaturan biologis seperti gerakan peristaltik usus yang dapat menyebabkan eliminasi mikroorganisme dan interaksi-interaksi yang terjadi antara berbagai macam species bakteri yang terdapat di dalam usus baik simbiosis maupun antagonis. Mikrobiota dalam usus ayam pedaging sangat berfruktuasi dan menjadi stabil pada umur enam minggu, oleh karena itu ayam yang baru menetas atau yang berumur dibawah tiga minggu sangat rentan terhadap infeksi $E$. coli. Kepekaan terhadap infeksi $E$. coli menurun dengan nyata sejalan dengan perkembangan mikrobiota normal dalam usus.

Mekanisme dan kandungan mikroflora yang amat kompleks dalam saluran pencernaan ayam pedaging dapat menyebabkan BAL tidak dapat beradaptasi dan bersaing dalam saluran pencernaan. Penggunaan prebiotik dan sinbiotik kedalam ransum ternyata dapat menstimulasi pertumbuhan BAL dan menurunkan kolonisasi bakteri $E$. coli pada saluran pencernaan (doudenum) ayam pedaging (Tabel 2). Hal ini ditunjukkan dengan populasi BAL pada douedenum ayam pedaging cenderung terjadi peningkatan dibandingkan dengan ayam pedaging yang diinfeksi maupun yang tidak diinfeksi $E$. coli. Menurut Gibson (2004) penambahan oligofruktosa (FOS) ke dalam ransum tidak mengubah total bakteri, akan tetapi menurunkan jumlah Bacteriodes, Clostridia dan Fusobacteria. Demikian pula menurut Abdel-Raheem et al. (2012) pemberian FOS tidak mengubah total mikrob, akan tetapi meningkatkan Bifidobacterium dan menurunkan Coliform. Gheisar et al. (2016), menyatakan bahwa penggunaan laktulosa mampu menstimulasi pertumbuhan probiotik Lactobacillus dan Bifidobacterium serta mereduksi aktivitas bakteri proteolitik. Penyerapan laktulosa juga mampu menghambat proliferasi bakteri patogen dalam usus seperti Salmonella dan E. coli dan meningkatkan pertumbuhan ayam broiler.

Pertumbuhan BAL tidak terpengaruh dengan adanya intervensi $E$. coli pada kelompok ayam yang diberi ransum mengandung prebiotik, probiotik dan sinbiotik. Meskipun terjadi sedikit penurunan jumlah BAL jika dibandingkan dengan kelompok ayam yang tidak diinfeksi $E$. coli, akan tetapi jumlahnya masih lebih tinggi dibandingkan dengan perlakuan kontrol. Hal ini menunjukkan bahwa penggunaan prebiotik, probiotik dan sinbiotik mampu menghambat pertumbuhan bakteri patogen yang masuk ke dalam saluran pencernaan ayam pedaging. Bakteri asam laktat yang distimulasi oleh prebiotik mampu bertahan akibat adanya intervensi patogen. Demikian pula pada perlakuan ransum sinbiotik, 
pertumbuhan BAL tidak terpengaruh dengan adanya intervensi $E$. coli dan jumlahnya tidak berbeda dengan jumlah pada kondisi tanpa infeksi $E$. coli.

Penggunaan prebiotik dan sinbiotik dalam ransum mampu mempertahankan jumlah BAL pada saluran pencernaan ayam pedaging baik pada kondisi infeksi E.coli maupun tanpa diinfeksi E.coli, terjadi penurunan jumlah BAL pada perlakuan kontrol, dan sedikit penurunan pada perlakuan probiotik. Meskipun demikian pada perlakuan prebiotik dan sinbiotik tidak menunjukkan perbedaan yang signifikan. Jumlah BAL pada perlakuan kontrol lebih rendah dibandingkan dengan perlakuan prebiotik dan sinbiotik, baik yang diinfeksi maupun yang tidak diinfeksi $E$. coli. Hal ini tidak terlepas dari mekanisme kerja probiotik yaitu melekat/menempel dan berkolonisasi dalam usus, berkompetisi terhadap makanan dan memproduksi zat anti mikrobial.

\section{SIMPULAN}

Penggunaan sinbiotik sebagai feed additive dalam ransum dapat memberi pengaruh positif terhadap gambaran histopatologi dan peningkatan populasi BAL pada duodenum ayam pedaging umur 2, 4 dan 6 minggu baik yang diinfeksi maupun tidak diinfeksi bakteri $E$. coli.

\section{SARAN}

Sinbiotik dapat digunakan sebagai feed additive pengganti antibiotik dalam ransum ayam pedaging dan selayaknya dapat menerapkan sistem pemeliharaan ayam pedaging secara intensif.

\section{UCAPAN TERIMA KASIH}

Ucapan terima kasih penulis sampaikan kepada Direktorat Riset dan Pengabdian Masyarakat, Direktorat Jenderal Penguatan Riset dan Pengembangan, Kementerian Riset, Teknologi, dan Pendidikan Tinggi yang telah memberikan dukungan dana dalam penelitian ini. Laboratorium Patologi, Fakultas Kedokteran Hewan, dan Laboratorium Mikrobiologi Seafast Center, Institut Pertanian Bogor yang telah menyediakan fasilitas dan memberi dukungan selama penelitian.

\section{DAFTAR PUSTAKA}

Abdel-Raheem SM, Sherief MSA, Hassanein KMA. 2012. The effects of prebiotic, probiotic and synbiotic supplementation on intestinal microbial ecology and histomorphology of broiler chickens. IJAVMS. 6(4):277-289.

Ashayerizadeh A, Dabiri N, Mizadeh KH, Ghobani MR. 2011. Effect of dietary supplementation of probiotic and prebiotic on growth indices and serum biochemical parameters of broiler chickens. J Cell and Animal Biology 5(8): 152-156.

Ballongue J. 2004. Bifidobacteria and Probiotic Action. 2004. Lactic Acid Bacteria Microbiol and Function Aspects. Ed ke3, Revised and Expanded. New York: Marcel Dekker, Inc Hlm. 67-124.

Balqis U, Darmawi, Hambal M. 2011. Goblet Cell Response Against Parasitic Disease In Laying Hens Treated With Excerotory /secretory of Ascaridia galli. Ukm-Bangi, Malaysia.

Fuller R. 1997. Probiotics 2: Application and Practical Aspect. London. Chapman and Hall.

Gheisar MM, Nyachoti CM, Hancock JD, Kim IH. 2016. Effects of lactulose on growth, carcass characteristics, faecal microbiota, and blood constituents in broilers. Veterinarni Medicina 61(2): 90-96.

Gibson GR. 2004. Fibre and effects on probiotics (the prebiotic concept). Clinical Nutr Suppl 1: $25-31$

Hartono EF, Iriyanti N, Suhermiyati S. 2016. Efek Penggunaan Sinbiotik Terhadap Kondisi Miklofora dan Histologi Usus Ayam Sentul Jantan. J Agripet 16(2): 97105.

Hashemi SR, Davoodi H. 2010. Phytogenics as new class of feed additive in poultry industry. J Anim Vet Adv 9: 2295-2304.

Khan I, Zaneb H, Masood S, Yousaf MS, Rehman HF, Rehman H. 2017. Effect of Moringa oleifera leaf powder supplementation on growth performance and intestinal morphology in broiler chickens. J Anim Physiol Anim Nutr 101 (Suppl.1) 114-121.

Laudadio V, Passantino L, Perillo A, Lopresti G, Passantino A, Khan RU, Tufarelli V. 2012. Productive performance and histological features of intestinal mucosa of broiler chickens fed different dietary protein levels. Poult Sci 91: 265-270. 
Marshall BM, Levy SB. 2011. Food Animals and Antimicrobials: Impacts on Human Health. Clin Microbiol Rev 24(4): 718735.

Salminen S, Yuan KL. 2009. Handbook of Probiotics and Prebiotics. $2^{\text {nd }}$ Edition. Hoboken, New Jersey. John Wiley and Sons, Inc.

Saragih HTSSG, Alawi MF, Rafieiy M, Lesmana I, Sujadmiko H. 2017. Pakan Aditif Ekstrak Etanol Lumut Hati Meningkatkan Pertumbuhan Morfologi Duodenum dan Perkembangan OtotDada Ayam Pedaging. J Veteriner 18(4): 617623.

Setiawan H, Utami LB, Zulfikar M. 2018. Serbuk Daun Jambu Biji Memperbaiki Performans Pertumbuhan dan Morfologi Duodenum Ayam Jawa Super. J Veteriner 19(4): 554-567.
Solanki HK, Pawar DD, Shah DA, Prajapati VD, Jani GK, Mulla AM. 2013. Development of microencapsulation delivery system for longterm preservation of probiotics as biotherapeutics agent. BioMed Research International 1-21.

Steel RGD, Torrie JH. 1995. Prinsip dan Prosedur Statistika. Edisi kedua. Jakarta. Gramedia.

Ventola CL. 2016. The Antibiotic Resistance Crisis Part 1: Causes and Threats. Pharm Ther 40(4): 277-283.

Yazdi FF, Ghalamkari G, Toghyani M, Modaresi M, Landy N. 2014. Efficiency of Tribulus terrestris L. as an antibiotic growth promoter substitute on performance and immune responses in broiler chicks. Asian Pac J Trop Dis 4: 1014-1018. 